\title{
INDICADORES METABÓLICOS SANGUÍNEOS DE GENOTIPOS LECHEROS EN PASTOREO DE LA PROVINCIA DE NAPO-ECUADOR
}

\author{
BLOOD METABOLIC INDICATORS OF DAIRY GENOTYPES GRAZING IN THE \\ PROVINCE OF NAPO-ECUADOR
}

\author{
Orlando Roberto Quinteros Pozo ${ }^{1, *}$, Julio Cesar Vargas Burgos ${ }^{1}$, \\ Ivana Barbona ${ }^{2}$, Pablo Roberto Marini ${ }^{2}$
}

1,* Universidad Estatal Amazónica, Km. 2. 1/2 vía Puyo a Tena (Paso Lateral) / 032-888-118, Puyo, Ecuador.

2 Universidad Nacional de Rosario, Facultad de Ciencias Agrarias, Calle Maipú 1065, Rosario, Santa Fe, Argentina.

*Author for correspondence: oquinteros@uea.edu.ec

\begin{abstract}
The aim of this study was to evaluate the energy-blood protein metabolism in dairy cows four genotypes first lactation under grazing in Canton Arosemena Tola, Napo, Ecuador. 36 dairy cows in first parity crosses of the genotypes were evaluated: Bos Indicus x Gir (GIR), Bos Indicus x Brown Swiss (BS), Bos Indicus x Jersey (J) and Bos indicus x Sahiwal (S). Blood samples coccygeal vein on days 60 and 21 were taken before of calving, the time of calving and at 30, 60 and 90 days after of calving. Values were determined in plasma, glucose, urea, creatinine, and total protein. None of the variables showed significant differences $(\mathrm{p} \geq 0.05)$ between races and the values obtained for all they were below normal values for dairy cows. Glucose showed no significant difference ( $p \geq 0.05$ ) over time. However, for urea, creatinine and total proteins were significant differences $(\mathrm{p} \geq 0,001)$ over time. One set was used Local regression smoothing parameter equal to 0.8 was to study how the trajectory of the variable over time. A mixed linear model for each variable then adjusted, considering a node in cases for which a change in the trajectory was observed at some particular time (as noted in the graph 1, 2, 3 Local regression). It was concluded that for the four dairy genotypes studied no differences were found in the concentration of metabolic indicators.

Keywords: Creatinine, gene groups, glucose, grazing system, total proteins, urea.
\end{abstract}




\section{Resumen}

El objetivo de este trabajo fue evaluar el metabolismo energético/proteico en sangre de vacas lecheras de cuatro genotipos de primera lactancia en condiciones de pastoreo en el cantón Arosemena Tola, Napo, Ecuador. Se evaluaron 36 vacas lecheras de primer parto cruzas de los genotipos: Bos Indicus x Gir (GIR), Bos Indicus x Brown Swiss (BS), Bos Indicus x Jersey (J) y Bos Indicus x Sahiwal (S). Se tomaron muestras de sangre de la vena coccígea los días 60 y 21 antes del parto, al momento del parto y a los 30, 60 y 90 días después del parto. Se determinaron los valores en plasma de, glucosa, urea, creatinina y proteínas totales. Ninguna de las variables presentó diferencias significativas $(\mathrm{p} \geq 0,05)$ entre razas y los valores obtenidos para todos se encontraron por debajo de los valores normales para las vacas lecheras. La glucosa no mostró diferencias significativas $(\mathrm{p} \geq 0,05)$ en el tiempo. En cambio, para Urea, Creatinina y Proteínas Totales existieron diferencias significativas $(\mathrm{p} \geq 0,001)$ a través del tiempo. Utilizando una regresión local con parámetro de suavizado igual a 0,8 para estudiar cómo era la trayectoria de la variable en el tiempo. Luego, se ajustó un modelo lineal mixto para cada variable, considerando un nodo en los casos para los cuales se observaba un cambio en la trayectoria en algún tiempo en particular (según lo observado en el gráfico 1, 2 y 3 de la regresión local). Se concluye que para los cuatro genotipos lecheros estudiados no se encontró diferencias en la concentración de los indicadores metabólicos.

Palabras claves: Creatinina, grupos génicos, glucosa, proteínas totales, sistema a pastoreo, urea.

Suggested citation: Quinteros, O., Vargas, J., Barbona, I. y Marini, P. 2017. Blood metabolic indicators of dairy genotypes grazing in the province of Napo-Ecuador. La Granja: Journal of Life Sciences. Vol. 26(2):119-130. pISSN:1390-3799; eISSN:1390-8596. 


\section{Introduction}

In the Ecuadorian Amazon, as in many countries, natural pastures are used as the main source of nutrients in cattle for milk or meat. These tropical systems offer comparative advantages as the production strategy is based on the exploitation of abundant solar energy for efficient photosynthesis of fast growing C4 grasses and water availability. But, faced with the abundance of forage, they are deficient in some nutritional components. Management systems, the quality and availability of forage, as well as the adaptation of the respective crosses of cattle to the specific environmental conditions play a crucial role in this context (Madalena, 2012).

Under tropical conditions, dairy cows are exposed to stressful climatic conditions associated with periods of high ambient temperature and solar radiation. In this adverse climate, different crosses with different milk potentials have been explored, trying to highlight their individual production with exotic breeds, however their adaptability is in doubt (Alameen and Abdelatif, 2012). Since there are still no conclusive studies for the Amazon region and even more for the genotypes under study.

And the same concluded Mancuso and Marini (2012), in their study, that the variations within each analyzed genotype and the different responses that each of them produces, does not adequately explain the possible adaptation of the animals to the environment and current management, therefore it is always necessary this type of studies.

The term metabolic profile was proposed by Payne et al. (1970), and it was an analysis of different blood parameters performed in dairy cows. This tool emerged as an auxiliary method in the diagnosis of so-called production diseases. According to Contreras (2000), the analysis of metabolic profiles, can contribute to the study of the nutritional balance of the rodeo, although this is not a nutritional test, but it indicates when the condition of homeostasis is altered (Wittwer, 2000).

One of the problems with dairy cattle in the tropics arises from the low consumption of dry matter, as a result of the poor quality of many tropical types of forage, as well as the depression of consumption due to caloric stress (Holmann et al., 2003).

Metabolic balance is deregulated in relation to protein/energy and nutritional status, which can be monitored through basic metabolites (Payne and Payne, 1987). From each of the metabolic pathways specific biochemical indicators can be selected (Díaz Gonzalez, 2000).

Some metabolic states are affected by the specific requirements of nutritional compounds, therefore the determination of the main metabolic indicators involved in the homeostatic processes constitutes a valuable tool for monitoring mineral supplementation and a factor of knowledge of possible causes of reproductive and productive behavior (Underwood and Suttle, 1999).

One of the most promising indicators is the level of blood urea, which reflects the balance between degradable protein and fermentable energy in the rumen (Hammond, 1997).

As for glucose, it can be used as a source of energy for the cells, as building units of galactose and subsequently lactose, or as a source of glycerol necessary for the synthesis of fat (Martínez Marín et al., 2010). The metabolic profile of the blood contributes a great deal of disinformation related to nutrition and animal health. In addition, it allows the identification of risk factors, such as nutritional imbalances, that may affect the productive and reproductive performance of the bovine herd.

The objective of this work was to evaluate the energetic and protein metabolism in blood of dairy cows from four lactation dairy genotypes under free grazing conditions.

\section{Materials and method}

\subsection{Design and study population}

A total of 36 cross breed dairy cows from four genotypes: Brahman $\times$ Gir (Gir), Brahman $\times$ Brown Swiss (BS), Brahman $\times$ Jersey (J) and Brahman $\times$ Sahiwal (S) were studied during the years 20142015, belonging to the dairy herd of the Center for Research, Postgraduate and Conservation of Amazonian Biodiversity (CIPCA), located in the canton of Arosemena Tola, in the province of Napo, Ecuador. $\left(01^{\circ} 14.325^{\prime} \mathrm{S}, 077^{\circ} 53.134^{\prime} \mathrm{W}\right)$ Area of 65 ha of pasture destined to dairy. The environment is tropical with rainfall of $4000 \mathrm{~mm} /$ year, an average relative humidity of $80 \%$ and temperatures varying between 15 and $25^{\circ} \mathrm{C}$. Its topography is characterized by slightly undulating reliefs without pronounced slopes, distributed in natural plateaus of great extension. The altitude varies between 580 and 990 m.a.s.l. Although the soils have a very heterogeneous composition, the majority originates in 
fluvial sediments coming from the Andean region of the country. The evaluated cows were reared under the same environmental, nutritional and management conditions.

Management. Blood samples were taken from the coccygeal vein on days 60 and 21 before delivery, at delivery and at 30,60 and 90 days postpartum. Cows had an average body weight of $315 \pm 37 \mathrm{~kg}$ (mean $\pm \mathrm{SD}$ ) and a production of $6.6 \pm 0.9$ liters (mean $\pm \mathrm{SD}$ ) per cow per day, were considered as experimental groups. $20 \mathrm{~mL}$ of blood was obtained from each animal in a sterile, clean glass test tube. Blood was centrifuged $(3,000 \mathrm{rpm}$ $\times 15-30 \mathrm{~min}$ ), the separated plasma was stored at $-20^{\circ} \mathrm{C}$ until analyzed. Plasma tests of Glucose, Urea, Creatinine and Total Proteins were performed using molecular spectrophotometry (Thermo Scientific, GENESYS 10 UV Series, Waltham, Massachusetts, USA), the reagents used were HUMAN, from Germany, Technical specifications for each of the samples according to their protocols, Glucose: Glucose liquicolor, Method GOD-PAP, glucose enzymatic colorimetric test. Urea: Urea liquicolor, Colorimetric enzymatic analysis for urea. Creatinine: Creatinine liquicolor. Jaffé reaction, Colorimetric photometric test for kinetic measurements of creatinine, Method without deproteinization. Total Proteins: Total Protein liquicolor. Photometric colorimetric test by total proteins. Method of biuret.

Nutrition and health. Bovine herd feeding in study was free grazing, with grasses based on Brachiaria decumbens $(17,585 \mathrm{~kg} \mathrm{DM} / \mathrm{ha} /$ year, Protein: 10,6\% Phosphorus: 0,18\%, In Vivo Digestibility of Dry Matter, DIVMS: $44,4 \%$ ), Brachiaria brizantha $(26,970 \mathrm{~kg} \mathrm{DM} / \mathrm{ha} /$ year, Protein: 10,1\%, Phosphorus: 0,18\%, In Vivo Digestibility of Dry Matter, DIVMS DIV: $4,1 \%)$, Arachis pintoi $(6,212 \mathrm{~kg} \mathrm{DM} / \mathrm{ha} /$ year, Protein: 19,4\%, Phosphorus: 0,21\%, In Vivo Digestibility of Dry Matter, DIVMS DIV: $59,2 \%)$, Desmodium ovalifolium $(5,890 \mathrm{~kg}$ DM/ha/year, Protein: 16,3\%, Phosphorus: $0,16 \%$, In Vivo Digestibility of Dry Matter, DIVMS DIV: 39,6\%) and Stylosanthes guianensis $(15,237 \mathrm{~kg}$ MS/ha/Year, Protein: 21,4\%, Phosphorus: 0,4\%, In Vivo Digestibility of Dry Matter, DIVMS DIV: 48,7\%). (Var- gas et al., 2015). The sanitary management usually used for the bovine herd of CIPCA was applied. It includes deworming, baths against ticks and flies, vaccinations for footand-mouth disease, bovine rabies and vesicular stomatitis and injectable application of vitamins and minerals.

\subsection{Data analysis}

An exploratory analysis of the data was performed, where averages and standard errors were estimated for the measured variables. In addition, graphs of average profiles for inspection and LOESS adjustments were performed to visually inspect the trajectory of the variables over time. Then, Mixed Linear Models were adjusted and in this way take into account the longitudinal nature of the data, considering as independent variables genotype and time. It was tested whether there were significant differences between genotypes. All statistical analyzes were performed using the JMP program in its version 5.0 for Windows (2003).

\section{Results}

The variable Glucose did not present significant differences $(p \geq 0,05)$ between breeds nor in time (Chart 1). Some of the data obtained are below the normal values for dairy cows $(2,50-4,16 \mathrm{mmol} / \mathrm{L})$, generally for all breeds on the $60^{\text {th }}$ and $21^{\text {st }}$ days of breeding do not reach the desired minimum. Then, there is no pattern since delivery at 90 days postpartum in all genotypes studied. Only BS cows from birth onwards have values within the normal range.

The result of the model showed that there are no significant differences $(p \geq 0,05)$ between breeds for the creatinine variable (Chart 2$)$, but there are significant differences $(p \geq 0,001)$ over time. Using the LOESS settings with a smoothing parameter equal to 0,8 , it was observed that the trajectory of the creatinine variable over time changes from birth. The obtained values are below the normal values for dairy cows $(105,4 \pm 35,6 \mathrm{mmol} / \mathrm{L})$ for almost all sampling and breed times. Creatinine values before delivery are well below the minimum range and then postpartum increase.

The result of the model showed that there are no significant differences $(p \geq 0,05)$ between breeds for 
Chart 1. Mean and standard errors of glucose in $\mathrm{mmol} / \mathrm{L}$ by breed and time

\begin{tabular}{cccccccc}
\hline \multirow{6}{*}{ Breed } & \multicolumn{6}{c}{ Time (days) } & \multirow{2}{*}{ Total } \\
\cline { 2 - 7 } & $\mathbf{- 6 0}$ & $\mathbf{- 2 1}$ & $\mathbf{0}$ & $\mathbf{3 0}$ & $\mathbf{6 0}$ & $\mathbf{9 0}$ & \\
\hline BS & $2,46 \pm 0,8$ & $2,35 \pm 1,4$ & $3,18 \pm 1,7$ & $2,75 \pm 0,8$ & $2,37 \pm 0,8$ & $3,20 \pm 0,9$ & $\mathbf{2 , 7 5} \pm \mathbf{1 , 2}$ \\
Gir & $2,39 \pm 0,7$ & $2,28 \pm 0,6$ & $2,52 \pm 0,5$ & $1,95 \pm 0,5$ & $2,85 \pm 0,6$ & $2,16 \pm 1,0$ & $\mathbf{2 , 3 6} \pm \mathbf{0 , 7}$ \\
J & $2,33 \pm 0,4$ & $1,73 \pm 0,7$ & $2,18 \pm 0,7$ & $2,31 \pm 0,5$ & $2,73 \pm 1,0$ & $2,75 \pm 0,5$ & $\mathbf{2 , 3 5} \pm \mathbf{0 , 7}$ \\
S & $2,16 \pm 0,9$ & $1,89 \pm 0,6$ & $2,31 \pm 1,0$ & $2,16 \pm 0,7$ & $2,76 \pm 0,6$ & $2,58 \pm 0,4$ & $\mathbf{2 , 3 0} \pm \mathbf{0 , 8}$ \\
Total & $\mathbf{2 , 3 3} \pm \mathbf{0 , 7}$ & $\mathbf{2 , 0 5} \pm \mathbf{1 , 0 3}$ & $\mathbf{2 , 6 0} \pm \mathbf{1 , 2}$ & $\mathbf{2 , 3 6} \pm \mathbf{0 , 7}$ & $\mathbf{2 , 6 4} \pm \mathbf{0 , 8}$ & $\mathbf{2 , 7 9} \pm \mathbf{0 , 8}$ & $\mathbf{2 , 4 7} \pm \mathbf{0 , 9}$ \\
\hline Brahman $\times$ Gir (Gir) & Brahman $\times$ Brown Swiss (BS), Brahman $\times$ Jersey $($ J) and & & &
\end{tabular}

Chart 2. Mean and standard errors of Creatinine in $\mathrm{mmol} / \mathrm{L}$ by breed and time

\begin{tabular}{|c|c|c|c|c|c|c|c|}
\hline \multirow{2}{*}{ Breed } & \multicolumn{6}{|c|}{ Time (days) } & \multirow{2}{*}{ Total } \\
\hline & -60 & -21 & 0 & 30 & 60 & 90 & \\
\hline BS & $41,8 \pm 18,8$ & $30,6 \pm 9,3$ & $33,2 \pm 14,7$ & $40,1 \pm 12,5$ & $80,0 \pm 28,7$ & $115,9 \pm 21,9$ & $\mathbf{5 9 , 3} \pm \mathbf{3 7 , 3}$ \\
\hline Gir & $35,4 \pm 6,4$ & $78,5 \pm 32,9$ & $50,2 \pm 24,8$ & $49,6 \pm 9,2$ & $102,0 \pm 42,5$ & $89,7 \pm 45,8$ & $66,9 \pm 38,7$ \\
\hline $\mathbf{J}$ & $37,1 \pm 6,9$ & $52,7 \pm 18,3$ & $44,2 \pm 9,4$ & $43,5 \pm 5,5$ & $110,0 \pm 25,8$ & $102,8 \pm 52,5$ & $\mathbf{6 5 , 7} \pm \mathbf{3 9 , 5}$ \\
\hline $\mathbf{S}$ & $32,74 \pm 13,4$ & $56,8 \pm 14,5$ & $66,7 \pm 13,2$ & $36,4 \pm 7,0$ & $127,2 \pm 39,1$ & $135,8 \pm 54,1$ & $75,2 \pm 48,7$ \\
\hline Total & $37,3 \pm 13,2$ & $\mathbf{5 3 , 1} \pm \mathbf{2 5 , 3}$ & $46,5 \pm 19,8$ & $41,9 \pm 10,1$ & $103,1 \pm 37,7$ & $111,62 \pm 45,4$ & $66,0 \pm 41,3$ \\
\hline
\end{tabular}

Gráfico de ajuste para Creatinina

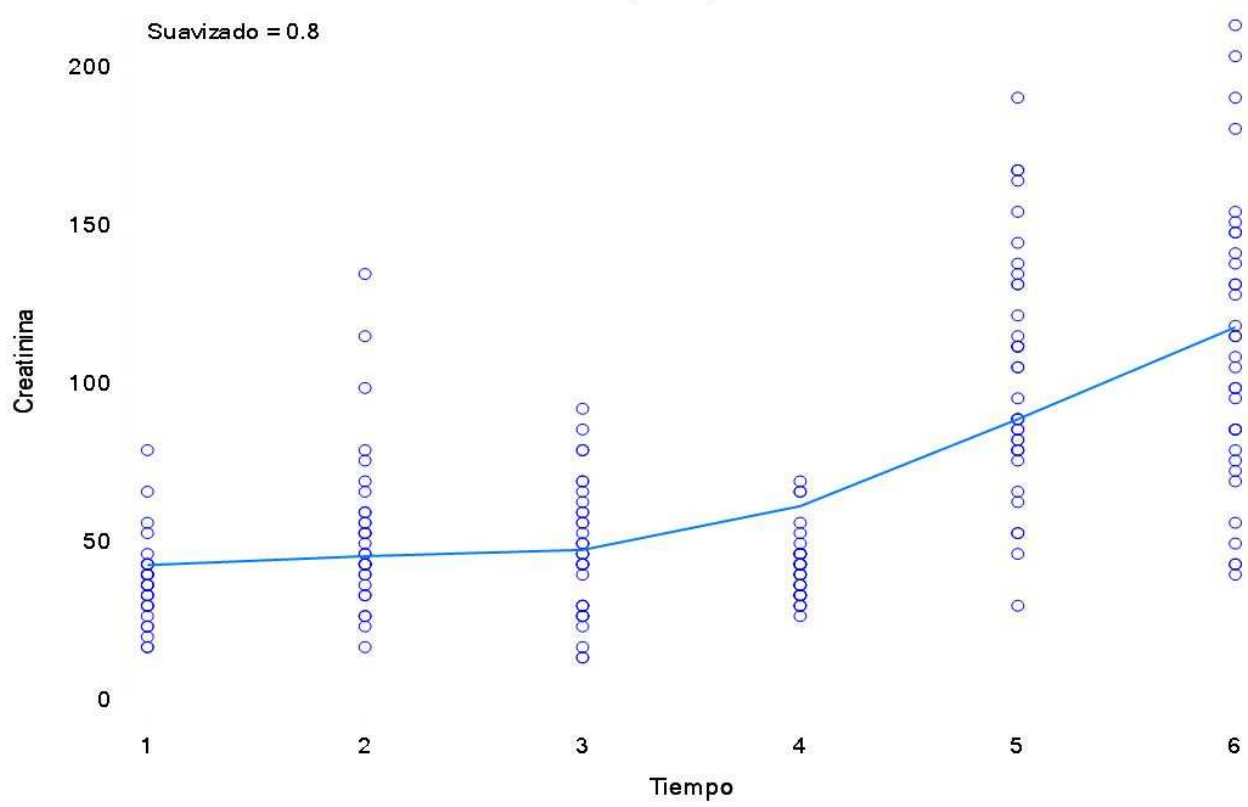

Figure 1. Creatinina fit 
the Urea variable (Chart 3), but there are significant differences $(p \geq 0,001)$ over time. Using the LOESS settings with a smoothing parameter equal to 0,8 , it was observed that the trajectory of the Urea variable in time changes from birth. The values obtained are within the range of normal values for dairy cows in the tropics, $(2,50-6,66 \mathrm{mmol} / \mathrm{L}$ or $15-40 \mathrm{mg} / \mathrm{dL})$, for almost all moments of sampling and breed.

The values of Urea decrease until the birth then return to grow onwards.

The results of the model showed that there are no significant differences $(p \geq 0,05)$ between breeds for the variable Total Proteins (Albumin and Globulins) (Chart 4), but there are significant differences $(p \geq 0,001)$ over time. Using the LOESS settings with a smoothing parameter equal to 0,8 it was observed that the trajectory of the variable Total Protein in time changes, being constant until the birth (time 0 ), whereas from this moment it begins to significantly descend ( $p \geq 0,001)$. Values obtained after calving are below the normal values for dairy cows $(6,62-7,28 \mathrm{~g} / \mathrm{dL})$.

\section{Discussion}

Inadequate feeding and mineral supplementation in cattle is one of the main constraints to cattle ranching in the tropical and Amazonian regions (Depablos et al., 2009), where low quality forage becomes the main and only source of feed (Sanchez, 2007). Whole blood and serum are widely used for studies of metabolic profiles and often preferable to forage and soil analyzes because they reflect a better contribution of the total diet (McDowell et al., 1984). There is a great deal of information on the metabolic profile of Holstein cows, but little in relation to different dairy crosses, which represent more than $70 \%$ of milk production in the tropics (Facó et al., 2002). Being the same situation in the Ecuadorian Amazon (Quinteros et al., 2016). In addition, the Amazon has a potential for milk production not yet evaluated, despite the difficulties of availability of quality food.

The increase in glucose on the day of delivery occurs very rapidly, falling after a few hours after delivery (De Aquino Neto, 2012). This increase is the result of a higher concentration of glucagon, catecholamines and glucocorticoids, which are mechanisms to prioritize the use of glucose by the mammary gland (Park et al., 2010). The low ove- rall glucose value found $(2,72 \mathrm{mmol} / \mathrm{L})$ may be indicating the low energy level of food (Margolles, 1983). In this study glucose levels were always below normal values and showed no trend during the whole period evaluated. The four genotypes showed no deference between them in the behavior, although it appears a better behavior in the BS, that is, with the same feed glucose levels were higher in the BS. Possibly the low milk production of these cows (7 \pm 1 liters) did not require high mobilization of body reserves to guarantee production, as can occur in high production Holstein cows ( +35 liters). The low glucose values for all breeds could be due to a poor energy intake in the daily ration. These results agree with Margolles (1983), who indicates that values lower than $2.41 \mathrm{mmol} / \mathrm{L}$ in dairy cows is given by low energy in the pastures and low supplementation with concentrate. The results also coincide with those of Margolles (1983), where it shows that grazing livestock does not suffer major changes in glycemia during lactation. Studies comparing blood glucose behavior among different genotypes found no difference in mean values between pure Holstein cows and their Swiss Brown crosses (Di Michele De Rosa et al., 1977), nor between Holstein and their crosses With Montbeliarde (Mendonça et al., 2014). However, Campos et al. (2007), mentions differences between seven specialized breeds (Ayrshire, Gir-Holando, Holstein Friesian, Jersey, Lucerne, Swiss and Simmental) for glucose and $\mathrm{BHB}$, among other metabolites in dairies in the Colombian tropics. Campos et al. (2007), emphasize the good performance of Jersey cows, which presented better homeostasis in glucose than the rest, especially compared to Holstein.

Creatinine values are a non-protein nitrogen compound commonly used in the evaluation of the renal excretion function (Gregory et al., 2004); in the study they did not show differences between genotypes, where pre-delivery values were below the lower limit and from it grew, possibly by an improvement of the body state. A study by Campos et al. (2007), found lower creatinine values in the lower weight animals (Jersey, Ayrshire) and in the animals with greater tendency to metabolic changes of weight and greater catabolism of muscle tissue showed the highest values (Simental, Gir-Holando). All values found were within international references, except the Jersey breed. The latter could have happened in the crosses analyzed in this study where the low creatinine value is associated with the 
Chart 3. Mean and standard errors of Urea in $\mathrm{mmol} / \mathrm{L}$ by breed and time

\begin{tabular}{|c|c|c|c|c|c|c|c|}
\hline \multirow{2}{*}{ Breed } & \multicolumn{6}{|c|}{ Time (days) } & \multirow{2}{*}{ Total } \\
\hline & -60 & -21 & 0 & 30 & 60 & 90 & \\
\hline BS & $5,83 \pm 1,9$ & $5,92 \pm 1,4$ & $5,40 \pm 1,8$ & $4,79 \pm 1,5$ & $5,04 \pm 1,5$ & $6,40 \pm 1,5$ & $5,53 \pm 1,7$ \\
\hline Gir & $7,11 \pm 1,1$ & $5,19 \pm 1,3$ & $4,64 \pm 0,8$ & $4,99 \pm 0,6$ & $6,76 \pm 1,0$ & $4,51 \pm 1,8$ & $5,56 \pm 1,5$ \\
\hline $\mathbf{J}$ & $6,00 \pm 2,2$ & $5,93 \pm 1,6$ & $4,11 \pm 0,9$ & $5,44 \pm 0,8$ & $5,97 \pm 1,8$ & $4,85 \pm 1,0$ & $5,37 \pm 1,6$ \\
\hline $\mathbf{S}$ & $5,66 \pm 1,2$ & $5,86 \pm 1,9$ & $4,46 \pm 1,7$ & $5,18 \pm 1,2$ & $4,91 \pm 1,3$ & $4,52 \pm 1,7$ & $5,13 \pm 1,6$ \\
\hline Total & $\mathbf{6 , 0 8} \pm \mathbf{1 , 8}$ & $5,77 \pm 1,6$ & $4,71 \pm 1,5$ & $5,09 \pm 1,2$ & $5,58 \pm 1,6$ & $5,30 \pm 1,7$ & $5,40 \pm 1,6$ \\
\hline
\end{tabular}

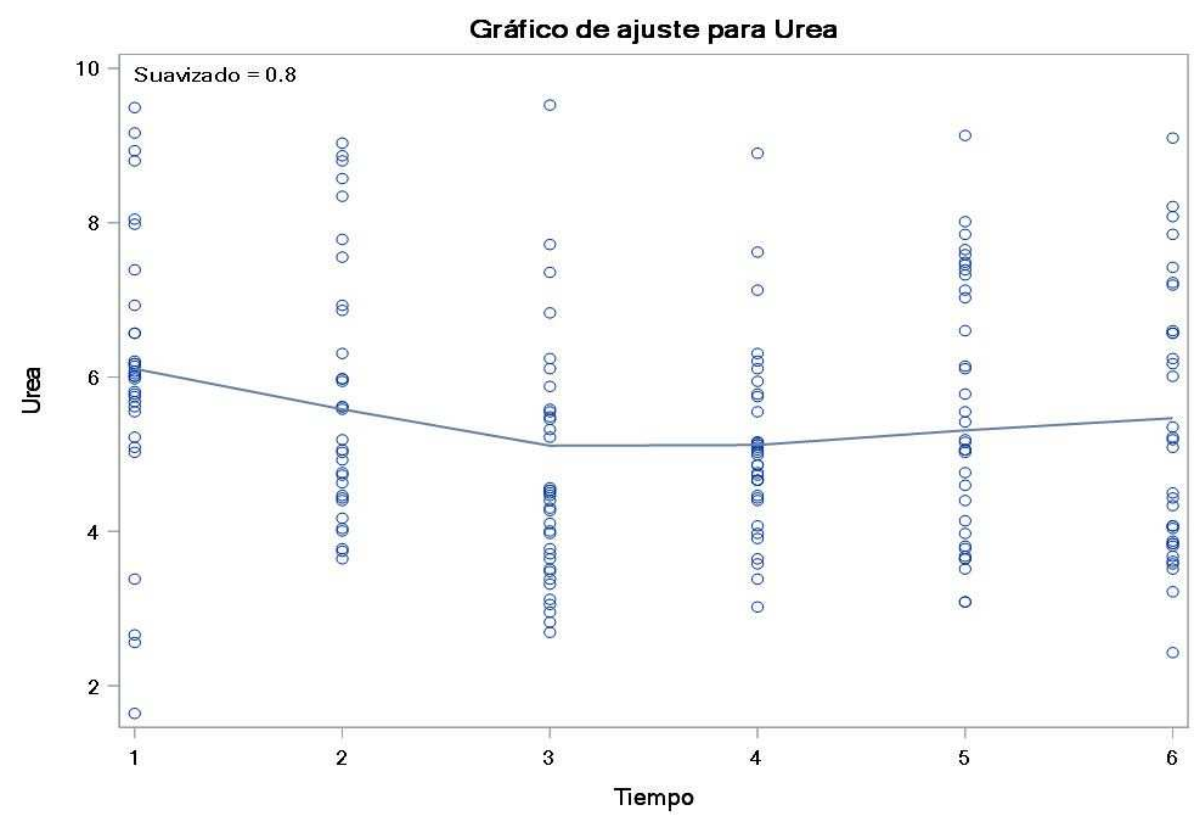

Figure 2. Urea fit.

Chart 4. Mean and standard errors of Total Proteins in $\mathrm{g} / \mathrm{dl}$ by breed and time.

\begin{tabular}{cccccccc}
\hline \multirow{2}{*}{ Breed } & \multicolumn{7}{c}{ Time (days) } \\
\cline { 2 - 7 } & $\mathbf{- 6 0}$ & $\mathbf{- 2 1}$ & $\mathbf{0}$ & $\mathbf{3 0}$ & $\mathbf{6 0}$ & $\mathbf{9 0}$ & Total \\
\hline BS & $9,47 \pm 0,9$ & $9,62 \pm 1,8$ & $8,34 \pm 0,9$ & $9,27 \pm 2,6$ & $5,00 \pm 1,3$ & $4,36 \pm 0,8$ & $\mathbf{7 , 5 1} \pm \mathbf{2 , 7}$ \\
Gir & $9,59 \pm 2,8$ & $8,77 \pm 0,8$ & $8,75 \pm 1,4$ & $7,45 \pm 1,9$ & $5,24 \pm 1,3$ & $4,92 \pm 1,3$ & $\mathbf{7 , 5 2} \pm \mathbf{2 , 5}$ \\
J & $8,18 \pm 1,2$ & $8,54 \pm 1,1$ & $7,87 \pm 1,5$ & $8,95 \pm 1,6$ & $5,40 \pm 0,9$ & $4,35 \pm 0,4$ & $\mathbf{7 , 1 5} \pm \mathbf{2 , 1}$ \\
S & $9,16 \pm 2,3$ & $9,16 \pm 1,4$ & $8,41 \pm 0,7$ & $8,19 \pm 0,7$ & $4,22 \pm 0,8$ & $3,84 \pm 1,1$ & $\mathbf{7 , 3 1} \pm \mathbf{2 , 5}$ \\
Total & $\mathbf{9 , 0 5} \pm \mathbf{1 , 9}$ & $\mathbf{9 , 0 6} \pm \mathbf{1 , 4}$ & $\mathbf{8 , 2 9} \pm \mathbf{1 , 2}$ & $\mathbf{8 , 6 4} \pm \mathbf{2 , 0}$ & $\mathbf{4 , 9 8} \pm \mathbf{1 , 2}$ & $\mathbf{4 , 3 5} \pm \mathbf{0 , 9}$ & $\mathbf{7 , 3 7} \pm \mathbf{2 , 5}$ \\
\hline
\end{tabular}

Brahman $\times$ Gir (Gir), Brahman $\times$ Brown Swiss (BS), Brahman $\times$ Jersey $(J)$ y Brahman $\times$ Sahiwal $($ S) 


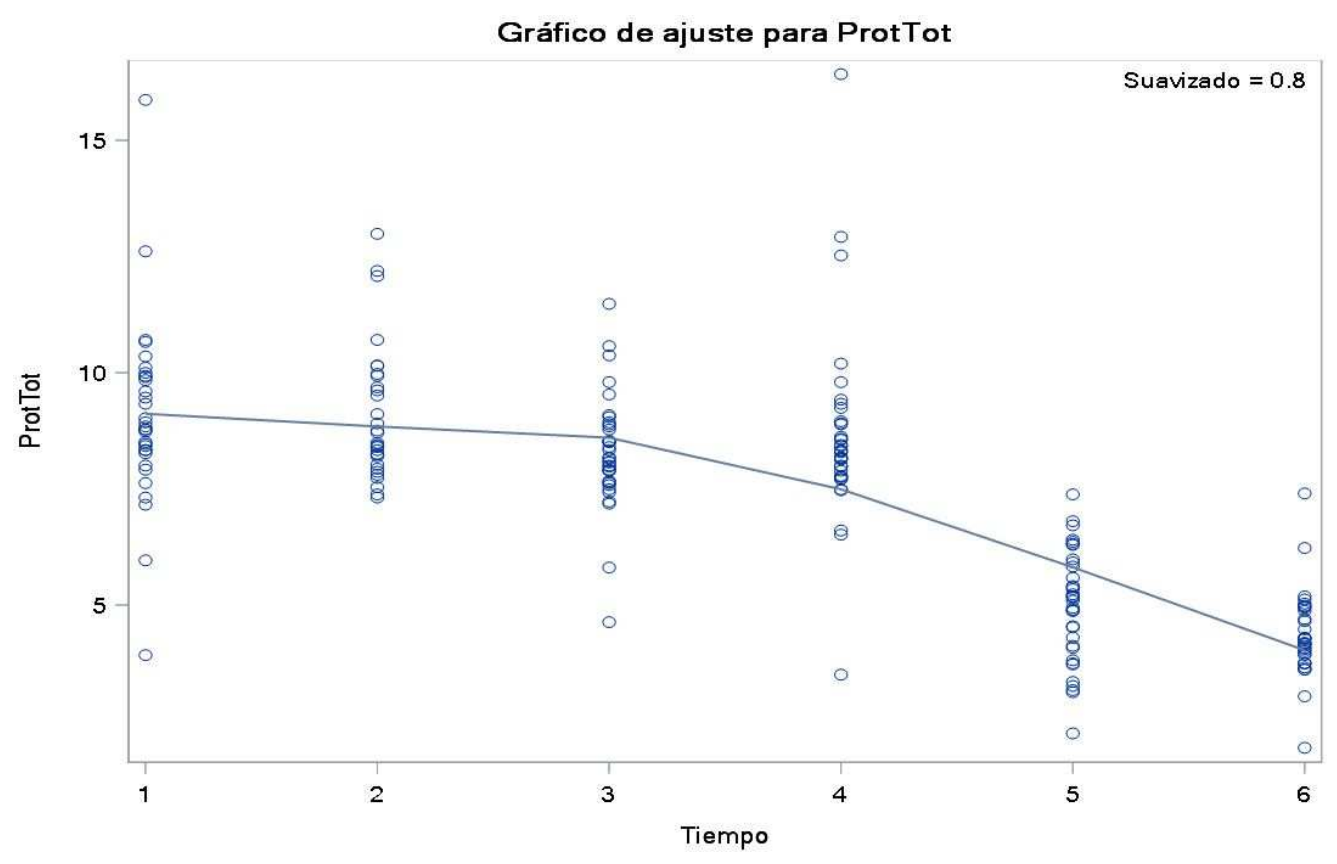

Figure 3. Urea fit.

body condition, because the mobilization of adipose and muscular tissue reflected in the low levels of reserves could cause the fall of creatinine by increase of the rate of excretion during the period of loss of body condition.

One of the most promising indicators is the level of blood urea, which reflects the balance between degradable protein and fermentable energy in the rumen (Hammond, 1997). The recommendations for crude protein concentration $(\mathrm{CP})$ in dairy cow rations range from $12 \%$ to $18 \%$ for cows in the first part of lactation, which is administered by mixing forages and concentrates (Coleman and Barth, 1977). The results obtained in this work showed a low blood urea presence in all the studied genotypes, possibly due to the low pasture quality (described in materials and methods) that did not meet the protein requirements (Butler et al. 1996, Nozad et al., 2012). A paper by Mancuso et al. (2016), found in dairy cows belonging to five types of crosses: $\mathrm{C}$ (Holstein $\times$ Jersey); P $(\mathrm{C} \times$ Swiss Brown $)$; $M(C \times$ Montbeliarde); G (C $\times$ Guernsey) and R $(\mathrm{P}, \mathrm{M}$ or $\mathrm{G}-$ without discriminating which of them $-\times$ Holstein) in grazing systems that the indicators of protein metabolism were found in the upper range with respect to the reference ones, which would relate to diets high in protein. In addition, no differences were found between genotypes with respect to urea le- vels. This response coincides with that reported by Hess et al. (1999), who indicated that one of the factors that determine urea levels in the blood is the diet given to the animal and the degree of degradability of the protein at the rumen level. In addition, the low energy input from consumed fodder. The values of Total Protein, behaved inversely to that of urea, since after the delivery they decreased to values below the normal range. Without showing differences between the studied breeds, in this case coinciding with works by Mancuso et al. (2014; 2016) where it did not find differences between the genotypes with respect to the levels of total protein. As for the influence of breeds on blood protein concentrations, Campos (2007) found differences in the concentrations of total proteins, albumin and globulins among different dairy breeds specialized in pastoral systems in Colombia, in another study Pereira Lorenzo et al. (2010), also found differences for total proteins, albumin and globulins, in pure Uruguayan Holstein cows with respect to their crosses with New Zealand Holstein, although they did not differ in plasma urea concentrations.

The global trend towards milk production from forages, international competitiveness that presses the reduction in production costs and the expansion of the agricultural frontier give countries in the tropical belt an opportunity to produce quality milk 
in a competitive way (Ibarra, 2004). The finding of energy-protein metabolic values below normal ranges would require the need to look at systems such as the one analyzed for the use of dairy cows adapted to the environment in order to take advantage of the competitive and comparative advantages of grazing systems, referenced to which Quinteros and Marini (2017) note, the objective of research in the Ecuadorian Amazon is to generate data capable of evaluating and improving the productive and reproductive behavior of local dairy genotypes under free grazing conditions.

Metabolites indicative of energy/protein status showed oscillations between the different gene groups, according to the physiological phase, therefore it can be concluded that a greater variation in the indicators show a greater metabolic demand (initiation of lactation). This variation is also due to the fact that one of the physiological changes that the cow presents when approaching breastfeeding is the increase in energy requirements, which may increase during the last month of preparation. During this physiological phase the consumption of food decreases leading to a cow with a negative energy balance that starts a month before delivery, is accentuated in the first week postpartum and can be extended up to the seventh week postpartum, this negative energy balance forces the cow to mobilize its body reserves forcing it to perform a metabolic adjustment with its subsequent implications (Cevallos et al., 2002). The usefulness in the determination in different physiological groups allows a better understanding of the management of the herd as a whole and produces adequate and integrated information through which changes or adjustments can be made in the alimentary, nutritional and sanitary management, in agreement with the proposed Nutritional analysis of Payne and Payne (1987). Although the metabolic indicators analysis is not a nutritional examination in and of itself, since the blood metabolites are not good indicators of the nutritional status of individuals, they indicate when the capacity of homeostasis has been altered, which is why they are indicators of the metabolic balance in animals (Hoff and Cote, 1988). The Metabolic Profile complements the indications of the nutritional balance. The number of variables that are potentially feasible to measure in a metabolic profile is unlimited, in practice only those with adequate knowledge about biochemistry and physiological role will be used, information that allows to inter- pret the obtained results. On the other hand, methods and equipment are also required to make the economically feasible determination and reference values to compare results (Wittwer, 2000).

\section{Conclusions}

It is concluded that for the four dairy studied genotypes no differences were found in the concentration of metabolic, energetic-protein values.

The reference values found for biochemical metabolites indicative of energy metabolism, protein, in four bovine gene groups for milk production under grazing conditions in tropical climate, are basic information for work in clinical pathology and physiology of adaptation.

The found values are reference for dairy cattle in the Ecuadorian Amazon.

\section{References}

Ahmed O. A., y Abdalla, M. A. 2012. Metabolic and endocrine responses of crossbred dairy cows in relation to pregnancy and season under tropical conditions. AmericanEurasian J. Agric. E Environ. Sci. Disponible en: https://goo.gl/Z8JxCY.

Andrés, L., Martínez, M., Pérez-Hernández, M., Pérez-Alba, L., Gómez-Castro, M., y CarriónPardo, D. 2010. Metabolismo de los lípidos en los rumiantes. Revista Electrónica de Veterinaria. 11(8), p.1-21. Disponoble en: https://goo.gl/jmqyAQ

Aquino Neto, H. M. 2012.Perfil hidroeletrolítico, ácido-base, metabólico e mineral de vacas leiteiras no pós-parto imediato e avaliação da fluido terapia oral. Tesis de doutorado, Universidade Federal de Minas Gerais. Disponible en: https://goo.gl/37Mpkc.

Butler, W. R., Calaman, J. J., y Beam, S.W. 1996.Plasma and milk urea nitrogen in relation to pregnancy rate in lactating dairy cattle. J. Anim. Sci. 74, p. 858-865. DOI: http://dx.doi.org/10.5935/1806-6690.20170081

Campos, R. G., Cubillo, C., y Rodas, A. G. 2007. Indicadores metabólicos en razas lecheras especializadas en condiciones tropicales en $\mathrm{Co}-$ 
lombia. Acta. Agron, 56, 2-10. Disponible en: https://goo.gl/yUrBb5

Cevallos, A., Gómez, P., Vélez, M., Villa, N., y López, L. 2002. Variación de los indicadores bioquímicos del balance de energía según el estado productivo en bovinos lecheros de Manizales, Colombia. Revista Colombiana de Ciencias Pecuarias. 15(1), p. 13-25. Disponible en: https://goo.gl/ddkzHf

Coleman, S. W., y Barth, K. M. 1977. Utilization of supplemental NPN and energy sources by beef steers consuming low protein hays. J. Anim. Sci., 45, p. 1180-1187. Disponible en: https://goo.gl/Y2yx6K

Contreras, P. 2000. Indicadores del metabolismo proteico utilizados en perfiles metabólicos de rebannos. Perfil metabólico en ruminantes. Brasil: Eds. Porto Alegre, p. 23. Disponible en: https://goo.gl/aq7csp

Depablos, L., Godoy, S., Chicco, C. y Ordóñez, J. 2009. Nutrición mineral en sistemas ganaderos de las sabanas centrales de Venezuela. Zootec. Trop., 27(1), p. 25-37. Disponible en: https://goo.gl/zU8Chq

Di Michele De Rosa, S., Otaiza, V. E., Colveé, M. P. y Mejía, E. B. 1977. Valores hematológicos y de la química sanguínea en bovinos de los estados Carabobo y Guárico. Hematología, colesterol y glucosa. Agron. Tropical, 27(6), p. 571583. Disponible en: https://goo.gl/soFZ5V

Facó, O., Lobo, R. N. B. y Martins Filho, R. 2002. Análise do desempenho produtivo de diversos grupos genéticos Holandês-Gir no Brasil. Rev. Bras. Zootec., 31, p. 1944-1952. DOI: http:/ / www.scielo.br/scielo.php?script=sci_ arttext\&pid=S1516-35982008000500006

González, F. H. D. 2000. Uso do Perfil Metabólico no Diagnóstico de Doena̧s Metabólico Nutricionais em Ruminantes. Perfil Metabólico em Ruminantes, Brasil: Eds. Porto Alegre, p. 89106. Disponible en: https://goo.gl/aq7csp

Gregory, L., Birgel, E. H. Jr., D’angelo, J. L., Benesi, F. J., Araujo, W. P. y Birgel, E. H. 2004. Valores de referencia dos teores séricos de uréia e creatinina em bovinos da raça Jersey criados no estado de Sao Paulo. Influencia dos fatores etários, sexuais e da infeccao pelos virus da leucose dos bovinos. Arq. Inst. Biol. Sao Paulo, 71(3), p. 339-345. Disponible en: https://goo.gl/ua8nZV

Holmann, F., Rivas, L., Carulla, J., Giraldo, L.A., Guzmán, S., Martínez, M., Rivera, B., Medina, A., y Farrow, A. 2003. Evolución de los sistemas de producción de leche en el trópico latinoamericano y su interrelación con los mercados: Un análisis del caso colombiano. Cali: CIAT, Consorcio Tropileche. 53p. Disponible en: https://goo.gl/DoSFHU

Hammond, A.C. 1997. Update on bun and mun as a guide for protein supplementation in cattle. University of Florida. Disponible en: https://goo.gl/gBG4y3

Hess, H. D., Florez, H., Lascano, C. E., Baquero, L. A., Becerra, A. y Ramos, J. 1999. Fuentes de variación en la composición de la leche y niveles de urea en sangre y leche en vacas en sistemas de doble propósito en el trópico bajo de Colombia. Past. Trop., 21(1), p. 33-42. Disponible en: https://goo.gl/NZw3RT

Hoff, B., y Cote, J. 1988. Guidelines for the submission of metabolic profiles in problem dairy herds. Anim. Ind. Branch, 368, p. 18. Disponible en: https://goo.gl/1j9nyi

Ibarra, A. A. 2004. Sistema de pagamento do leite por qualidade, visão global. Congresso Brasileiro de Qualidade do Leite, p. 72-87. Disponible en: https://goo.gl/1d8nhD

Madalena, F. E. 2012. Animal breeding and development - South American perspective. J. Anim. Breed. Genet. 129(3), p. 171-172. Disponible en: https://goo.gl/zSj657

Mancuso, W. A., Marini, P. R. 2012. Comportamiento de vacas lecheras primíparas y sus cruzas en un sistema a pastoreo de Entre Ríos (Argentina). Rev. vet. 23(2), p. 138-143. Disponible en: https://goo.gl/poZ3J4

Mancuso, W. A., Marini, P. R. y Dunleavy, M. 2014. Indicadores metabólicos y condición corporal de genotipos lecheros en un sistema de Entre 
Ríos, Argentina. $37^{\circ}$ Congreso de la Asoc. Argentina de Producción Animal. Revista Argentina de Producción Animal, 34(1), p. 45-75. Disponible en: https://goo.gl/xjBje9

Mancuso, W. A., Marini, P R. y Dunleavy, M. 2016. Peso vivo, condición corporal e indicadores metabólicos en sangre, de vacas lecheras cruza. $39^{\circ}$ Congreso de la Asoc. Argentina de Producción Animal. Revista Argentina de Producción Animal, 36 (1), p. 33-70. Disponible en: https://goo.gl/2tUnK8

Margolles, E. 1983. Metabolitos Sanguíneos en Vacas Altas Productoras Durante la GestaciónLactancia en las Condiciones de Cuba y su Relación con Trastornos del Metabolismo. Rev. Cub. Cienc. Vet., 14 p. 221-230. Disponible en: https://goo.gl/1KmuXf

McDowell, L. R., Conrad, J., Ellis, G. y Loosli, J. 1984. Minerales para Rumiantes a Pastoreo en Regiones tropicales. Departamento de Ciencia Animal. CIAT. Universidad de Florida y Agencia de los EUA para el Desarrollo Internacional.

Mendoną, L. G. D., Abade, C. C., Da Silva, E. M. N., Litherland, B., Hansen, L.B. y Chebel, R.C. 2014. Comparison of peripartum metabolic status and postpartum health of Holstein and Montbeliarde-sired crossbred dairy cows. J. Dairy Sci., 97, p. 805-818. DOI: http:/ /dx.doi.org/10.3168/jds.2013-7159

Nozad, S., Ramin, A. G., Moghadam, G., AsriRezaei, S., Babapour, A. y Ramin, S. 2012. Relationship between blood urea, protein, creatinine, triglycerides and macromineral concentrations with the quality and quantity of milk in dairy Holstein cows. Veterinary Research Forum, 3(1), p. 55-59. Disponible en: https://goo.gl/N71WPV

Park, A. F., Shirley, J. E. y Titgemeyer, E. C. 2010. Characterization of plasma metabolites in Holstein dairy cows during periparturient period. J. Dairy Sci., 5, p. 253-263. DOI: http:/ /dx.doi.org/10.3923/ijds.2010.253.263

Payne, J. M., Dew, S. M., Manston, R. y Faulks, M. 1970. The use of metabolic profiles test in dairy herds. Vet. Rec., 87(6), p. 150-158. Disponible en: https://goo.gl/wYeXk7
Payne, J. M., Payne, S. 1987. The metabolic profile test. Oxford University Press. p. 179 Disponible en: https:/ /goo.gl/it4RcE

Pereira Lorenzo, I., Laborde, D., Carriquiry, M., López-Villalobos, N. y Meikle, A. 2010. Blood metabolic profiles in Uruguayan Holstein and Uruguayan Holstein x New Zealand Holstein - Friesian dairy cows. Proceedings New Zealand Society of Animal Production, 70, p. 311315. Disponible en: https://goo.gl/92tzBu

Quinteros, R., Vargas, J. C., Moreno, L., Barbona, I. y Marini, P. R. 2016. Valores de $\mathrm{pH}$ en sangre en cuatro genotipos lecheros en condiciones de pastoreo libre en la Amazonía ecuatoriana. Revista de Biosfera, Huellas del Sumaco, 16(2). ISSN 1390-6801.

Quinteros-Pozo, R. y Marini, P. R. 2017. Evaluación productiva y reproductiva de cuatro genotipos lecheros en pastoreo libre en la Amazonía ecuatoriana. Rev. vet. 28(1), 9-13. Disponible en: https://goo.gl/hfsNN2

Sánchez, J. M. 2007. Utilización eficiente de las pasturas tropicales en la alimentación del ganado lechero. XI Seminario de Pastos y Forrajes en Sistemas de Producción Animal. Barquisimeto, Venezuela. abril, 2007. Disponible en: https://goo.gl/kR3VUS

Underwood, E. J. y Suttle, N. F. 1999. Mineral nutrition of livestock. Edinburgh, UK.: $\mathrm{CAB}$ International, 456p. Disponible en: https://goo.gl/Q4dhuW

Vargas, J., Benítez, D., Bravo, C., Leonard, Ismael., Pérez, M., Torres, V., Ríos, S. y Torres, A. 2015. Retos y posibilidades para una ganadería sostenible en la provincia de Pastaza de la Amazonía ecuatoriana. Puyo, Ecuador. ISBN: 978-9942-932-16-7.p. 174 Disponible en: https://goo.gl/5Dzs5p

Wittwer, F. 1994. Diagnóstico de desbalances metabólicos nutricionales en animales de producción. En: Congreso Nacional de divulgación en técnicas de RIA y evaluación de metabolitos sanguíneos y cinéticas digestivas relacionadas con nutrición y reproducción. Maracay, 1, Venezuela. Disponible en: https://goo.gl/PQJ95j 
Wittwer, F. 2000. Diagnóstico dos desequilíbrios metabólicos de energia em rebanhos bovinos. Perfil metabólico em ruminantes: seu uso em nutrição e doenças nutricionais. Porto Alegre: UFRGS, 9-22 Disponible en: https://goo.gl/aq7csp 